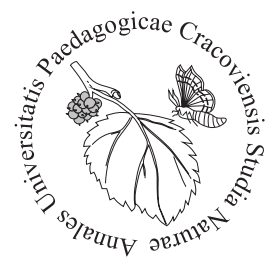

Anna Kocoń, Magdalena Nowak-Chmura*

Department of Invertebrate Zoology and Parasitology, Institute of Biology, Cracow Pedagogical University, Cracow, Podchorążych 2, 30-084 Cracow, Poland; *magdalena.nowak-chmura@up.krakow.pl

\title{
Skin ectoparasites of domestic animals
}

Small pets have long accompanied their owners and play a positive role and strengthen their owners' psychological well-being and their physiological welfare, as their life companions. According to research by Krassowska (2014), the majority of Poles that have pets at home choose a dog (Canis familiaris L.) (83\%), fewer people decide on a cat (Felis catus L.) (44\%), the third place of the most popular animals accompanying Poles at home are birds (4\%), rodents (3\%), and reptiles (1\%).

The frequent phenomenon in accompanying animals is the infestation of their skin by insects or parasitic mites, causing onerous symptoms, such as discomfort, itching, or allergic reactions. Due to the close contact of people with pets, we are also exposed to the attacks of dangerous arthropods, causing, e.g., pediculosis, sarcoptosis, otodectomy, and demodicosis and transmitting many dangerous zoonotic diseases, such as Lyme disease tularaemia, rickettsiosis, ehrlichiosis, and others. Skin ectoparasites that most often attack domestic animals are mites (e.g., Demodex spp., Sarcoptes spp., ticks) and insects such as fleas and lice (Tab. 1). Symptoms of attacks of dangerous ectoparasites may include skin itching, allergic reactions, skin redness, discomfort, the loss of hair, and skin discoloration. Because of the rapid reproduction of parasites, immediate assistance is required for animals attacked by parasitic arthropods, primarily to protect the animals against parasite infestation on the whole body and against the destruction of the animal's organism. The prevention and protection against the attacks of skin ectoparasites is important, because, by protecting the animals we also protect ourselves against zoonotic diseases.

Review of the selected domestic animals and ectoparasites attacking them

1. Dog (Canis familiaris L.)

The dog is the most common domestic animal in Polish homes (Krassowska, 2014), and the oldest domesticated carnivore mammal. It probably derives from the grey 
wolf (Canis lupus L.). The period of taming falls approx. 12 thousand years ago, when the portion of the grey wolf population was approaching human habitation. Initially, man used the help of dogs to hunt and to guard the herds. As a result of more or less conscious selection and crossing, about 400 breeds and varieties of a domestic dog have been grown. The breeds vary among themselves, with height, body weight, appearance, utility, and colour. The excellent sense of smell, hearing, good olfactory and auditory memory, the ability of spatial orientation, intelligence, and the ease of attachment to people facilitate its education and training.

Demodex canis Leydig - dog demodex (Appendix 1 - Fig. 1a), is a widespread animal parasite observed in nearly $80 \%$ of dogs. It occurs in the hair follicles and sebaceous glands, and sometimes also in the lymph nodes, internal organs, and blood. It

Tab. 1. Skin ectoparasites of domestic animals

\begin{tabular}{|c|c|c|c|}
\hline No. & Parasite species & Host & $\begin{array}{l}\text { Parasitic disease/carrier (vector) } \\
\text { of the diseases }\end{array}$ \\
\hline 1. & Demodex canis & Canis familiaris & demodicosis \\
\hline 2. & Sarcoptes scabiei var. canis & C. familiaris & sarcoptosis \\
\hline 3. & Ctenocephalides canis & C. familiaris & ktenocefalidosis/vector \\
\hline 4. & Linognathus setosus & C. familiaris & lice \\
\hline 5. & Cheyletiella yasguri & C. familiaris & cheyletiellosis \\
\hline 6. & Trichodectes canis & Canis familiaris, Felis catus & malofagosis \\
\hline 7. & Ixodes ricinus & C. familiaris, F. catus & vector \\
\hline 8. & I. crenulatus & C. familiaris, F. catus & vector \\
\hline 9. & I.hexagonus & C. familiaris, F. catus & vector \\
\hline 10 & I. rugicollis & C. familiaris, F. catus & vector \\
\hline 11. & Dermacentor reticulatus & C. familiaris, F. catus & vector \\
\hline 12. & Otodectes cynotis & C. familiaris, F. catus & otodectomy \\
\hline 13. & Notoedres cati & Felis catus & sarcoptosis \\
\hline 14. & Demodex cati & F. catus & demodicosis \\
\hline 15. & Cheyletiella blakei & F. catus & cheyletiellosis \\
\hline 16. & Ctenocephalides felis & F. catus & ktenocefalidosis \\
\hline 17. & Felicola subrostratus & F. catus & malofagosis \\
\hline 18. & Dubininia melopsittaci & Melopsittacus undulatus & 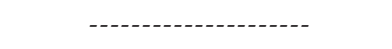 \\
\hline 19. & Sideroferus lunula & M. undulatus & 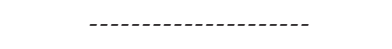 \\
\hline & Neopsittaconirmus gracilis & M. undulatus & malofagosis \\
\hline 21. & Trixacarus caviae & Cavia porcellus & 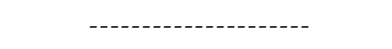 \\
\hline 22. & Chirodiscoides caviae & C. porcellus & \\
\hline 23. & Gliricola porcelli & C. porcellus & malofagosis \\
\hline 24. & Demodex cavinae & C. porcellus & demodicosis \\
\hline 25. & D. criceti & Mesocricetus auratus & demodicosis \\
\hline 26. & D. aurati & M. auratus & demodicosis \\
\hline 27. & D. flagellurus & Mus musculus & demodicosis \\
\hline 28. & D. musculi & M. musculus & demodicosis \\
\hline
\end{tabular}


occurs naturally in small amounts in most dogs, and it usually does not cause clinical symptoms. Occasionally, the mite can cause a disease called mange, and then lead to one of the most onerous skin problems encountered in veterinary practice (Gauguere, 1994). The infection with demodex already takes place in the first days of the life of puppies, most often during feeding, or being licked by the mother. In older dogs, the infection may take place through direct contact. Human infection is very rare. Factors affecting the mange in animals at a young age include the occurrence of metabolic disorders, malnutrition, systemic infections and cancers, diabetes, as well as a decreased resistance to natural factors, and stress. The most common symptoms of the attack of $D$. canis are skin peeling, the appearance of purulent pimples coming out of the hair follicles, increased pigmentation, thinning of the hair, and red erythematous spots. Skin lesions appear mainly around the head, muzzle, lips, ears, torso, and less frequently in the paw area, and if so, on the front paws. Heavy and generalised mange may lead to the death of the animal (Gauguere, 1994).

Sarcoptes scabiei L. var. canis - dog itching mites (Appendix 1 - Fig. 1b) causes a disease called sarcoptosis. Mites attack many mammals, including humans and most livestock and domestic animals. Dog scabies is very infectious among dogs. The most vulnerable are dogs living in poor environmental conditions or staying in larger concentrations, e.g., in shelters or animal hotels with poor maintenance standards. Mites can survive up to two weeks in the host, so the transmission does not require physical contact with other infected animals, because they are passively transmitted in close contact with the host. This parasite spends all his life on the same host. Dogs may pick up mites from the nearest environment. S. scabiei does not have external vectors (insects, worms, birds), which carry these mites, as is the case with many other ectoparasites. Mites burrow tunnels under the skin. Their saliva has strong digestive enzymes, which dissolve the skin tissues, and they do not suck blood. Adult females lay their eggs in subcutaneous tunnels, which hatch within a few days. Dog scabies will last only a few days without the host. Damages caused by parasites may be significant. The tunnels cause skin irritation, which increases the allergic reactions to saliva and faeces excretion of the mites. Pimples and lumps grow on the infected skin, the animal's fur is brittle, and the skin becomes bald and hard, which results in the formation of skin folds. The initial symptoms of the mite infection include redness and small balding areas near the lips, eyes, ankles or elbows, and on the periphery of the ears, where the skin is thin, which then spread to the rest of the body, most often covering the elbows, armpits, chest and abdomen of the animal (Klockiewicz, 2003).

Dogs infected with S. scabiei suffer from severe itching, shaking their heads, often lick the infected parts of their body, vigorously scratch their head, ears, and they rub against objects (trees, furniture, etc.) which sometimes leads to self-mutilation. 
Untreated disease causes the destruction of the body and may lead to the death of the animal (Klockiewicz, 2003).

Ctenocephalides canis Curtis - dog flea (Appendix 1 - Fig. 1c) is an external parasite, cosmopolitan, whose main hosts most often include dogs (C. familiaris), foxes (Vulpes vulpes L.), and grey wolves (C. lupus). These fleas can also parasitize humans, cats, and other mammals (Sandner, 1976). Eggs laid by the female fleas are most often found in the animal's litter. In neglected, sick dogs, the eggs can be laid directly on the skin. This insect can transmit the plague, endemic dandelion, as well as be the intermediate host of flea tapeworm (Dipylidium caninum (L.) Leuckart) and the vector of roundworm larvae Dirofilaria immitis Leidy. Infestation with fleas, called ktenocefalidosis, results in animal anxiety, itching caused by the irritating secretions introduced into small wounds along with saliva. Strong itching often causes scratching and rubbing of the dogs against various objects, leading to secondary skin lesions, particularly in such areas of the body like the head, neck and tail (Stefański, 1968). This constant scratching and biting of the skin can cause the dogs skin to become red with inflammation, and the dog can also lose hair. Dog fleas can cause allergic dermatitis in dogs allergic to the saliva of these insects. In this case, the above-mentioned symptoms are more pronounced. These ectoparasites can also result in the animal's anaemia, when fleas suck up a very large amount of blood in young, elderly, or sick individuals (Patyk, 1978). Fleas occur in a variety of environments, and they rapidly spread to another host by leaping, so it is important to take care of the hygiene of your animal and your own and to use specialist fleafighting preparations.

Linognathus setosus Olters - dog louse (Appendix 1 - Fig. 1d) is a cosmopolitan ectoparasite, and it causes a disease called pediculosis. It infests the hairy scalp, ears, neck, back, and near the root of the tail, spreading to the whole body in the case of a severe infestation. Nits, lice eggs, are fixed by the female with the so-called cement, at the base of the hair, usually visible to the naked eye with a bigger number of eggs. Most of the time, the louse is a practically still animal (Sadzikowski, Gundłach, 2004). Dog lice are not common in clean, healthy, well fed, and maintained accompanying dogs. However, it often attacks weakened, old, exhausted, and malnourished animals. Attacked dogs are anxious, are itching, and often scratching, which leads to intense licking, rubbing, and biting of the infected areas. The animal's fur becomes rough and the skin is reddened, which can lead to dermatitis. Infestation with lice may lead to anaemia (Blagburn et al., 1981). Unlike fleas, lice do not jump from one dog to another, but they can move from one host to another through direct contact with the infected dog, e.g., in the animal shelter, in parks, or in other places with a lot of dogs. Due to the fact that lice cannot survive a long time outside the host, they cannot be found freely in the 
environment, which distinguishes them from, e.g., fleas and ticks. Infected dogs can be quickly and easily cured with specialised insecticides.

Cheyletiella yasguri Smiley - cosmopolitan mite (Appendix 1 - Fig. 1e), Cheyletiella spp. is responsible for causing the skin disease called cheyletiellosis, which, due to its symptoms, is often called 'walking dandruff'. The name 'walking dandruff' comes from the dynamically moving mites in search of food between the exfoliated skin in which they move, thus making the skin move. These ectoparasites live on the skin surface and feed on keratin, the main structural skin protein, exfoliated skin, hair, and skin secretions. They periodically attach themselves to the skin of the host, which they pierce with mandibles and suck out the exudates coming out from the skin micro-damages (Bronswijk, Kreek, 1976). Cheyletiella spp. are absolutely bound to their host, and they are not likely to survive outside their host in the environment. These mites can be transmitted between different animal species, including humans, and in addition, some animals (mainly rabbits and cats). The infection usually has a direct character by rubbing, licking the fur, sleeping or playing together. Therefore, all dogs can be the potential source of threat to each dog, but also other domestic animals (mainly cats and rabbits), as well as humans. These mites have been found on insects bigger than themselves with a parasitic lifestyle, e.g., on fleas, mice, and flies, which is important for the spread of Cheyletiella spp. among various mammals, including dogs. In very few cases, infections may also occur through indirect contact (shared blankets, toys, towels, etc.). The risk of infection increases in large groups of dogs, among young animals, or sick ones with a weakened immune system, and among malnourished or poorly nourished individuals. Dogs with long hair are more susceptible to infections. Itching and dandruff are the most characteristic symptoms of the invasion. Sick animals are restless, and they are scratching, licking, shaking, or rubbing against various objects incessantly, which may lead to skin damage, numerous wounds, or thinning hair. Continuous peeling of the epidermis makes the animals look as if they were sprinkled with flour. Dandruff is located in the area of the hindquarters, from where it extends to the back - along the spinal line - to the head. As a result of scratching, the mites spread to other parts of the body, sometimes covering the whole body. Continuous scratching leads to skin eruptions, and lesions may be accompanied by severe seborrhoea and a very unpleasant odour. At an advanced stage, it may involve weight loss, sadness, apathy, fever, and systemic complications (Saevik et al., 2004).

Trichodectes canis De Geer - chewing lice, a cosmopolitan parasite of dogs and cats (Appendix 1 - Fig. 1f). It dwells on the whole body, in the hair, mainly on the neck and head (Stefański, 1968). T. canis is a well-known vector for Dipylidium caninum. Usually, it does not pose serious problems to the host; however, in severe infections, it can be very irritating. Wild, sick, neglected dogs are often attacked by this ectoparasite. This parasite mainly feeds on the fluids produced by the irritated skin. It causes stress 
in the host, creates wounds on the surface of the skin, and it also leads to hair loss due to increased scratching, and biting the hair out (Sadzikowski, Gundłach, 2004). Dogs in Poland are also attacked by four tick species from the Ixodidae family: Ixodes ricinus L., I. crenulatus Koch, I. hexagonus Leach, I. rugicollis Schulze et Schlottke and one species from the Amblyommidae family: Dermacentor reticulatus Fabricius. There have also been cases of bringing the Rhipicephalus sanguineus Latreille species to Warsaw, a typical dog parasite, which does not occur in the Polish fauna. Moreover, probably also other tick species can attack domestic dogs and cats in Poland (Ixodes persulcatus Schulze, Haemaphysalis punctata Canestrini \& Fanzago and H. concinna Koch) (Siuda et al., 2007). Ticks thrive on the hosts body most often in places well supplied with blood vessels, on delicate skin, which are difficult to access for the animals own hygiene: around the snout, behind the ears, on the back of the neck, the neck, on the back and groin, at the base of the tail or around the anus (Siuda, 1993).

Ixodes ricinus L. - common tick (Appendix 1 - Fig. 2a) is the most common and widespread species of ticks in Poland that attacks domestic dogs and cats (Siuda et al., 2002, 2004; Nowak-Chmura, Siuda, 2012). This parasite is the vector and carrier of many pathogens, which are dangerous, due to the fact that they cause serious medical and veterinary consequences, the most important ones include, among others, the following: Borrelia burgdorferi, B. garinii, B. afzelli, virus from the Flaviviridae family, Rickettsia slovaca, R. conorii, Anaplasma phagocytophilum, Coxiella burnetti, Toxoplasma gondii, Theileria mutans, and others (Nowak-Chmura, Siuda, 2012; Nowak-Chmura, 2013). Narrow lanes, forest paths, tall grass, bushy scrubs, and deciduous and mixed forests are ideal walking locations for domestic dogs, and thus perfect conditions for I. ricinus to attack the host (Siuda, 1993).

I. hexagonus Leach - hedgehog tick (Appendix 1 - Fig. 2b) are nest and burrow parasites, which can also occur in the near vicinity of dog kennels, in close proximity to human homes and settlements (Hillyard, 1996; Siuda, Nowak, 2011). It is probably spread throughout Poland (Michalik et al., 2010; Kilar, 2011; Nowak-Chmura, 2013). The tick-borne encephalitis virus, Borrelia burgdorferi, B. garinii, B. afzelii, Rickettsia helvetica, Anaplasma phagocytophilum are the main pathogens transmitted by this tick species (Nowak-Chmura, 2013). Another tick species found in domestic dogs in Poland is Ixodes rugicollis (Siuda et al., 2010). The natural habitat of I. rugicollis usually includes burrows, mammal hiding places, low humidity habitats (nest and burrow parasite) (Nowak-Chmura, 2013). The medical and veterinary significance of I. rugicollis has not been fully investigated.

I. crenulatus Koch - is also a nest and burrow species, the parasite dwells in burrows of predatory mammals and rodents. It easily adapts to various habitats: lowlands, mountains, subalpine meadows, deserts (Mihalca et al., 2012). The tick was found in different places throughout Poland (Siuda, 1993; Kadulski, 2007; Siuda et al., 2010). 
The role of this species in the transmission of infectious diseases is poorly known. It is the carrier of Coxiella burnetii and an important vector of Borrelia burgdorferi $\mathrm{s}$. in areas where I. ricinus is absent (Estrada-Peña et al., 1995).

Dermacentor reticulatus Fabricius, meadow tick - the main habitat of this tick species includes wooded, bushy river valleys, streams, swampy mixed forests (Szymański, 1986). There is a currently widespread coverage of this species in Central Europe and in neighbouring countries (Dautel et al., 2006; Nowak, 2011; Petney et al., 2012). The largest number of habitats of this tick can be found in the north of Poland, in the areas of north-eastern and eastern Poland (Siuda, 1993; Bogdaszewska, 2004; Kadulski, Izdebska, 2009; Nowak-Chmura, 2013). D. reticulatus is a significant vector of tick-borne pathogens in Europe, the greatest importance is related to the transmission of Babesia canis protozoa, and this is the main etiologic agent of the 'babesiosis canum' disease. This disease can lead to the dysfunctions of many of the host's body organs. The outbreaks of this disease have also been documented in Poland (Zygner et al., 2007, 2008; Welc-Falęciak et al., 2009). Domestic dogs should be checked after each walk for the presence of ticks, especially around the ears, mouth, eyes, and the whole torso. Proper hygiene should be maintained while removing the feeding ticks.

2. Domestic cat (Felis catus L.)

The domestic cat is the second most common animal accompanying Polish families (Krassowska, 2014), and currently the most popular pet in the world (Driscoll et al., 2009). This species probably originates from the Nubian cat (Felis silvestris ssp. lybica Forster), and it was domesticated about 9.5 thousand years ago. For a few thousand years, about a hundred breeds of the domestic cat have been bred, varying in hair colour, length, and size. A large number of domestic cats live alone in towns and villages. Previously, cats were used for killing mice and rats, which were destroying the farmers' harvests before domestication of cats; in addition, they were taken hunting in order to scare the game (Lasota-Moskalewska, 2005).

Otodectes cynotis Hering - scabies (Appendix 1 - Fig. 2c). It infests the external auditory duct of domestic cats, less often in dogs. In advanced cases, it can attack other areas of the body: neck, back, loin, and tail. The infection occurs through direct contact with the sick individual. It is much more common in kittens than adult cats. The microorganism can also be transferred to humans. Considerable amounts of dark brown, waxy, dry secretions can be observed in the auricle, where these microorganisms accumulate. In the advanced state of the disease, the accumulated grease can clog the auditory canal, which leads to the situation where a cat cannot hear. An untreated invasion can damage the tympanic membrane. Symptoms of scabies, the disease caused by this parasite, is a characteristic strong itching of the ears, during which the cat is shaking its head, scratching its ears and crooking its head, which is 
due to the mechanical and chemical tissue irritation by the ectoparasites preying in them. Infection is also accompanied by local allergic reactions, local inflammation, and severe pruritus. Constant itching forces the animal to continue scratching causing further irritation of the infected areas, thus leading to the aggravation of disease symptoms and mechanical spread of parasites to other body areas. Skin lesions appearing on the skin take the form of localized balding and severely itchy follicular efflorescence (Bowman, 2012).

Notoedres cati Hering - feline scabies (Appendix 1 - Fig. 2d). These parasites are transmitted directly from a diseased individual to a healthy one; however, sometimes the physical contract is not required, because they can be easily collected in places shared with sick individuals. They resemble the Sarcoptes scabiei mites both in terms of construction and behaviour. The infection often covers the animals head and ears, and then it spreads to the neck, back, and other parts of the body. The skin affected by the invasion of itchy mites is wrinkled, with hair loss, often with scabs on it. The symptoms of the feline mite invasion include intense itching, vigorous and continuous scratching, and licking of the infected body parts. From time to time, the Notoedres mites can infect humans, but are unable to complete their development on them (Kotomski, 2000).

Demodex cati Hirst - feline demodex (Appendix 1 - Fig. 2e), as in the case of Demodex canis, it may occur as a natural flora in healthy cats. Skin lesions associated with the invasion of feline demodex tend to be localised on the head, neck, and eyelids, where they cause hair thinning and alopecia. It can also lead to seborrhoea, the formation of lumps, pustules, and skin inflammation. Mites can also be present in the auditory canals, causing the inflammation of the middle ear (Dembele, 2000).

Cheyletiella blakei Smiley - small mites and ectoparasites of domestic cats. Cheyletiellosis, the disease caused by this microorganism, can be transferred from cats to humans. Cheyletiella yasguri occurring in dogs and C. blakei occurring in cats are absolutely not specific to typical hosts. The presence of mites on the animal's skin may be tolerated well by them, and excessive peeling of the skin is the only clinical symptom of infestation; however, other animals may develop itching with varying degrees of severity. The symptoms of a cat being attacked by the mite are similar to the symptoms of domestic dogs being attacked by C. yasguri (Appendix 1 - Fig. 2f) (Fagasiński, 2000).

Ctenocephalides felis Bouche - feline flea (Appendix 1 - Fig. 2g). A cosmopolitan parasite, in addition to a domestic cat, it can also attack humans, domestic dogs and other domestic and wild animals. Symptoms of cat infestation by fleas are the same as in the case of $C$. canis infestation of domestic dogs, i.e. severe itching that causes constant scratching and rubbing at various objects, which leads to skin lesions in areas of the body, such as the head, neck, and tail areas. The animal's skin becomes red, often balding (Furmaga, 1985). 
Felicola subrostratus Nitzch in Burmeister - a lice species, cosmopolitan, occurring all over the body in the hair (Appendix 1 - Fig. 2h). It is found in older or sick cats, especially in longhaired breeds. In case of invasion, the cat is constantly scratching, biting the areas with the itchy skin, rubbing, and is restless. The longer dwelling time of the lice on the body and their increasing number causes the skin redness, numerous scratches on the skin, and the loss of hair by the animal (Kotomski, 2000). Domestic cats are attacked mainly by four tick species: Ixodes ricinus, I. crenulatus, I. hexagonus and I. rugicollis (Siuda et al., 2007; Kocoń et al., 2017), which were described above for the domestic dog.

\section{Budgerigar (Melopsittacus undulates Shaw)}

Budgerigar has been the most popular parrot occurring in breeds all over the world for over 200 years. The main places where the parrots occur include steppes overgrown with various species of grass. It is a nomad species, if the food runs out in the place where it lives, it moves to another area. Parrots are relatively easy to tame, especially because they are usually accompanied by people from birth. They first appeared in Europe in 1840, in England, and for the next 20 years, they have spread in breeding in other parts of Europe. The essential food for budgerigars includes the properly selected grain mix, including millet, canary grass, Senegal millet, Japanese millet, oats, and a small amount of oil seeds. In 2012, 28 varieties of parrots were described (Bielfield, 1997).

Dubininia melopsittaci Atyeo \& Gaud and Sideroferus lunula Robin \& Mégnin - acari, which do not normally threaten their hosts, look like mites. Bigger invasions take place as a result of stress, poor nutrition, and inappropriate living conditions of the parrots, as well as due to the reduced animal immunity. Under such conditions, these parasites reproduce in excess, which causes skin irritation for the birds, but they do not lead to feathers falling out. It is believed that D. melopsittaci (Appendix 1 Fig. 3a) is more pathogenic than S. lunula (Appendix 1 - Fig 3b). S. lunula is usually located on large wing feathers and tail, while D. melopsittaci on smaller ones. These species are located in different places and do not compete with each other. They spent all their lives dwelling among the host's feathers. They move very well between the feathers, thanks to 'sticking' to the feathers, so they do not fall off during the flight. They feed mainly on the feathers with the glandular secretions, exfoliate skin, nd the feather residues. Parasites pass from one bird to another during direct contact with the infected animal, especially during breeding, from adults to chicks. The symptoms of invasion of these mites are scratching by the parrots and plucking feathers. Changes in the appearance of the feathers are visible on the underside of the feather, where these parasites dwell, and the feathers appear greasy, stained, and devoid of natural glow. In budgerigars, apathy, anorexia, and the destruction of the body may occur during very large invasions. Mite allergens can cause irritation of the skin and mucous membrane 
in humans (Atyeo, Gaud, 1987).

Neopsittaconirmus gracilis Guimaraes - lice, one of the feather-eating species (Appendix 1 - Fig. 3c). This parasite feeds on the feather residues, exfoliated epidermis, and adult lice, as well as larvae, can actively collect blood. The invasion is usually asymptomatic, as a result of a decrease in immunity, and bad conditions. Mass infestation causes clinical symptoms, such as bird anxiety and weakness of the body. The infection takes place through direct contact of birds, but sometimes they can get infected in the nest. They also nibble on the base of the feathers, causing bleeding damage to the skin, and scabs form in the lesion areas. They can cause inflammation and allergic reactions on the skin, which often manifests as pruritus. Additional skin damage occurs when birds are pecking the itchy spots. Symptoms of feather-eaters feeding on the feathers (flag loss, flag holes) and eggs laid by them along the feather can be seen with the naked eye. However, the visible losses in the flags do not always denote the presence of feather-eaters, and they can be the effect of mechanical damage. These lice are most often found on the back of the head and neck; however, during larger invasions, they cover the whole body (Sychra, 2005).

\section{Guinea pig (Cavia porcellus L.)}

Cavy is a rodent species, commonly known as guinea pigs, which were domesticated by South American Indians, who used them for many purposes, including culinary, ritual, and folk medicine. It came to Europe as a hobby animal in the XVI ${ }^{\text {th }}$ and XIX ${ }^{\text {th }}$ centuries, and it was used as a laboratory animal. The guinea pig is a herbivore, and it is well suited for hobby breeding. C. porcellus should not be kept alone, because it is a social animal, and it maintains close relations with the herd members. Currently, there are many breeds and colour varieties of this rodent. These breeds are different in terms of structure and length of hair (Beck, 2014).

Trixacarus caviae Fain, Hovell \& Hyatt - mites that move directly from the infected animal to another one, and they rarely leave their host. In guinea pigs, they cause scratches, biting of the skin, hair loss, and in severe cases, seizures (Appendix 1 - Fig. 3d). With severe infection, they can be life threatening due to the lack of food, severe pain, and discomfort. They are not transferred to humans. In healthy animals, the mites can be dormant for several months or years, becoming a problem in pregnant, sick, stressed, and older guinea pigs (Mederle, Indre, 2009).

Chirodiscoides caviae Hirst (Appendix 1 - Fig. 3e), mites that cause minor discomfort, even if they are present in large quantities, do not show signs of harmful effects on the rodent. Sometimes, they are visible to the naked eye on the animal's fur, attached to the hair. They do not cause skin irritation, in some cases, they can cause itching (d'Ovidio, Santoro, 2014).

Gliricola porcelli Schrank (Appendix 1 - Fig. 3f) are lice that most often infest the 
guinea pig. Lice are visible to the naked eye in the rodent's hair, and they feed on hair and exfoliated skin. Because of their high species specificity, they do not pose a threat to other animals or humans. The infection occurs through direct contact with a sick animal. The course of the disease may be asymptomatic. With more severe invasions, the animals experience pruritus, and they rub against objects or scratch the itchy areas, which leads to the formation of wounds. However, we usually observe only the deterioration in the quality of the coat, with its thinning and seborrhoea. With severe, long-lasting, and untreated invasions, the lichenification of the skin around the ears can be observed, as well as seizures (Przyjałkowki, 1977).

Demodex caviae Bacigalupo (Appendix 1 - Fig. 3g), demodex attacking guinea pigs. The symptoms of the occurrence of $D$. caviae are the same as in the case of $D$. canis and D. cati described above (Hawkins, Bishop, 2012).

\section{Golden hamster (Mesocricetus auratus Waterhouse)}

It is the most well-know hamster species, which is a rodent, bred as a pet. This species was first described in 1839 by the British zoologist, Waterhouse. M. auratus did not stand out with special features, the interest in it was not high, and over time, it was observed less and less, until finally it was considered to be the extinct species. In 1930, professor Aharoni from the University of Jerusalem, who conducted excavations in Syria, found a female with young ones. Three individuals from this family ( 2 females and a male) went to England, where zoologists created favourable conditions for them to live and breed, and the hamster population grew rapidly. The first hamsters were imported to Poland in 1950 from France. The rodent feeds mainly on plant food (Stromenger, 1995).

Demodex criceti Nutting \& Rauch and $\boldsymbol{D}$. aurati Nutting - demodex are the most commonly ectoparasite recognised in hamsters. $D$. criceti and $D$. aurati initially do not cause any clinical symptoms on the skin, and they usually feed naturally on the animal. D. criceti, is a smaller mite (Appendix 1 - Fig. 4a) than D. aurati (Appendix 1 - Fig. $4 \mathrm{~b}$ ), while $D$. aurati is more pathogenic. The symptoms of demodex invasion are rough coat, skin inflammation, balding, mainly on the back. The sick, old, and undernourished animals are attacked most often (Karaer et al., 2009).

\section{House mouse (Mus musculus L.)}

The house mouse is a species of small mammals, which is synanthropic and cosmopolitan. It probably derives from mice inhabiting prairies and semi-desert areas. Currently, it can be found wherever humans live, and it is omnivorous. Thanks to high reproduction and a lack of high breeding requirements, mice are willingly used as laboratory animals and are also grown at homes. It has very high adaptability capabilities (Zientek, 2015). 
Demodex flagellurus Bukva and D. musculi Oudemans - demodex is most common in mice. D. flagellurus (Appendix 1 - Fig. 4c) occurs mainly in the Czech Republic. In Poland, the species has been found in the northern and central parts of the country, but there is no detailed information about this parasite. D. flagellurus is one of the largest known mites in mice, and it is mainly found near the genital area. They spread easily between hosts. In some populations, they show a high degree of rodent infestation. No symptoms of the diseases were noted for these demodex on the animals' skin. D. musculi is associated with the areas of the whole body and it has also been observed in wild populations of mice and laboratory mice (Izdebska, Rolbiecki, 2015).

\section{Conclusions and recommendations}

External parasites are important factors in the health of domestic animals and humans. They cause skin damage and pathological reactions from the immune system. They also play a role as a source of many types of pathogenic agents and can have negative effects on the bonds that exist between humans and animals. Other negative effects of parasitic infestation are skin lesions leading to secondary bacterial or fungal infections, as well as dermatitis. Under the influence of contact with saliva of the ectoparasites, allergic reactions may occur. The most important of which is the allergic flea dermatitis (Sadzikowski, Gundłach, 2004). Due to the transfer of pathogens by ectoparasites that cause diseases in many cases with more clinical relevance than the parasite infestation itself, caring for our animals is particularly important.

When deciding on a pet, we should be aware of such dangers and carefully combat the dangerous ectoparasites to keep our pets in good health and fitness. Organisms with an invasion of external parasites can be a source of infestation for their owners or other animals living in the same area, which can be a huge problem. The direct infestation of the host by ectoparasites may not be limited only to the skin level, but it can also lead to anaemia in the case of arthropods that suck blood in large quantities.

In the years 2012-2014, the presence of ectoparasites collected from domestic animals was studied in cooperation with veterinary clinics in the Silesian and Lesser Poland voivodeships. Skin and hair samples were collected from 77 infected hosts (62 from Lesser Poland, 15 from Silesia). The following species dominated among the mites: Otodectes cynotis var. cati (85.6\%), O. cynotis var. canis (4.4\%), Demodex canis (5.2\%), Cheyletiella yasguri (3.5\%). The presence of the following was found in smaller numbers: Sarcoptes scabiei var. canis (0.8\%), Notoedres cati (0.2\%), Chirodiscoides caviae $(0.1 \%)$. Out of the external insects, the majority of rat lice were collected - Polyplax spinulosa (92.9\%), Gliricola porcelli (3.1\%), Columbicola columbae (2.2\%), Ctenocephalides felis (1.3\%), and Ceratophyllus gallinae (0.4\%) (Pawełczyk et al., 2016).

The studies on demodecid mites found that the most common species attacking 
domestic dogs is Demodex canis; moreover, two other species can be found in dogs: D. injai occurring in adult sick dogs with hypothyroidism and Cushings syndrome, and $D$. cornei, which often causes seborrheic dermatitis. All of these species occur in Poland. Three species of demodex were also observed in cats: the most common D. cati, D. gatoi causing highly infectious lesions, described at homes, where a lot of cats live together, and D. felis. Two species were found in the golden hamsters $D$. criceti and D. aurati, and in mice - D. arvicolae found in the skin of the eyelids and around the eyes, and D. flagellurus (Jańczak et al., 2017).

In the years 2003-2007, 382 specimens of bred reptiles imported to Poland were studied, belonging to the species: Testudo sp., Iguana sp., Varanus sp., Gongylophis sp., Python sp., Spalerosophis sp., and Psammophis sp., from which the ticks were collected. The most infected reptiles came from Ghana (Africa) and these were Varanus exanthematicus Boso and Python regius Shaw. During the entire study, 2104 tick specimens were collected of the Amblyomma genus (detected in Poland for the first time): Amblyomma exornatum Koch, A. flavomaculatum Lucas, A. latum Koch (most abundant), A. nuttalli Dönitz, A. quadricavum Schulze, A. transversale Lucas, A. varanense Supino, Amblyomma spp. and Hyalomma: H. aegyptium L. Studies were also performed in terms for the presence of pathogens. In two ticks, Ambylomma flavomaculatum, the presence of Anaplasma phagocytophilum Dumler et al. was detected (Nowak, 2010).

Frequent weather changes, frequent journeys, frequent changes in the locations of the animals probably affect the existing epizootic situation of some external parasites and the pathogens they carry, and they can cause the spread of these organisms to new areas. This may lead to an increase in the incidence of rare parasitic diseases. Domestic animals, which accompany us on a daily basis, not only play a positive role, but also a negative one, because they are a perfect source for carrying numerous ectoparasites. We should pay special attention to keeping our animals healthy by protecting them against attacks by dangerous parasites. In the case of the ectoparasite invasion, we should prevent the widespread infestation as soon as possible. By taking care of the health of our animals, we also care for our own health.

\section{References}

Atyeo, W.T., Gaud, J. (1987). Feather Mites (Acarina) of the Parakeet, Melopsittacus undulatus (Shaw) (Aves: Psittacidae). The Journal of Parasitology, 73, 203-206.

Beck, A. (2014). Świnki morskie. Warszawa: Wydawnictwo Buchmann. [In Polish] Bielfield, H. (1997). Papużki faliste. Warszawa: Wydawnictwo Multico. [In Polish]

Blagburn, B.L., Todd, K.S., Herman, G.A. (1981). Pediculosis (Linognathus setosus) in a dog. Modern Veterinary Pracitce, 62(7), 544-545.

Bogdaszewska, Z. (2004). Występowanie i ekologia kleszcza łąkowego Dermacentor reticulatus (Fabricius, 1794) w ognisku mazurskim. I. Określenie obecnego zasięgu występowania. Wiadomości Parazytologiczne, 50(4), 731-738. [In Polish] 
Bowman, D.D. (2012). Parazytologia weterynaryjna. Georgis. Wrocław: Elsevier Urban \& Partner.

Bronswijk, J.E.M.H., Kreek, E.J. (1976). Cheyletiella (Acari: Chryletiellidae) of dog and cat and domesticated rabbit, a review. Journal of Medical Entomology, 13(3), 315-327.

Cheyletiella yasguri. Świat czarnego teriera. http://www.swiatczarnegoteriera.republika.pl/a-zdrowie_ choroby_chejletielle.html

Cheyletiellosis in cats. Cheyletiella sp. Cheyletiella spp. http://vetbook.org/wiki/cat/index.php?title=Cheyletiella_spp

Chirodiscoides caviae. European Scientific Counsel Companion Animal Parasites. https://www.esccap. fr/60-diagnose/fiches-de-diagnose/221-chirodiscoides-caviae.html

Ctenocephalides canis. Featured Creatures Entomology and Nematology University of Florida Entomology and Nematology Department. http://entnemdept.ufl.edu/creatures/urban/occas/dogflea.htm

Ctenocephalides felis. Line drawing of Ctenocephalides felis, Animal Parasites, Pinterest. https://pl.pinterest.com/pin/28429041375307898/

Dautel, H., Dippel, C., Oehme, R., Hartelt, K., Schettler, E. (2006). Evidence for an increased geographical distribution of Dermacentor reticulatus in Germany and detection of Rickettsia sp., RpA4. International Journal of Medical Microbiology, 296, 149-156.

Demodex aurati. Karaer, Z., Kurtdede, A., Ural, K., Sari, B., Cingi, C.C., Karakurum, M.C., Haydardedeoğlu, A.E. (2009). Demodicosis in a Golden (Syrian) hamster (Mesocricetus auratus). Ankara Üniversitesi Veteriner Fakultsei Dergisi, 56, 227-229. https://www.researchgate.net/figure/299182864_fig2_ Figure-2A-Demodex-aurati-Sekil-2A-Demodex-aurati

Demodex canis. Spencer Greenwood BSc, MSc, PhD, DVM. Department of Biomedical Sciences. Atlantic Veterinary College. University of Prince Edward Island. http://people.upei.ca/sgreenwood/html/ arthropods.html

Demodex cati. Diagnosis of Demodicosis in Dogs \& Cats. Clinician's Brief. https://www.cliniciansbrief. com/article/diagnosis-demodicosis-dogs-cats

Demodex cavinae. Happy Knuffel's. http://www.happy-knuffels.de/demodex-ssp.html

Demodex criceti. Karaer, Z., Kurtdede, A., Ural, K., Sari, B., Cingi, C.C., Karakurum, M.C., Haydardedeoğlu, A.E. (2009). Demodicosis in a Golden (Syrian) hamster (Mesocricetus auratus). Ankara Üniversitesi Veteriner Fakultsei Dergisi, 56, 227-229. https://www.researchgate.net/figure/237790982_fig2_ Figure-2B-Demodex-criceti

Demodex flagellurus. Karaer, Z., Kurtdede, A., Ural, K., Sari, B., Cingi, C.C., Karakurum, M.C., Haydardedeoğlu, A.E. (2009). Demodicosis in a Golden (Syrian) hamster (Mesocricetus auratus). Ankara Üniversitesi Veteriner Fakultsei Dergisi, 56, 227-229. https://www.researchgate.net/publication/273770550_New_data_on_occurrence_of_Demodex_flagellurus_Acari_Demodecidae_-_rarely_recorded_parasite_from_the_house_mouse_Mus_musculus_Rodentia_Muridae

Dembele, K. (2000). Nużyca psów i kotów (Demodicosis). Magazyn Weterynaryjny, 9, 23. [In Polish]

d'Ovidio, D., Santoro, D. (2014). Prevalence of fur mites (Chirodiscoides caviae) in pet guinea pigs (Cavia porcellus) in southern Italy. Veterinary Dermatology, 25(2), 135-137.

Driscoll, C.A., Clutton-Brock, J., Kitchener, A.C., O’Brien, S.J. (2009). The evolution of house cats. https://www.scientificamerican.com/

Dubininia melopsittaci. Federmilben. http://www.federmilben.de/04.htm

Estrada-Peña, A., Oteo, J., Estrada-Peña, R., Cortazar, C., Osacar, J., Moreno, J., Castella, J. (1995). Borrelia burgdorferi sensu lato in ticks (Acari: Ixodidae) from 2 different foci in Spain. Experimental and Applied Acarology, 19(3), 173-180.

Fagasińki, A. (2000). Cheyletielloza u psów i kotów. Magazyn Weterynaryjny, 9, 27. [In Polish] 
Feather-easting on feather flags. Centrum hodowlane - Tadeusz Kowalczyk. http://www.golebiepocztowe.eu/09/09af_45.html

Felicola subrostratus. Mites and Parasites. http://mites-and-parasites.org/felicola-subrostratus-the-cat-louse/

Furmaga, S. (1985). Choroby pasożytnicze zwierząt domowych. Warszawa: Państwowe Wydawnictwo Rolnicze i Leśne. [In Polish]

Gauguere, E. (1994). Główne ektoparazytozy psów i kotów. Magazyn Weterynaryjny, 3, 11. [In Polish]

Gliricola porcelli. European Scientific Counsel Companion Animal Parasites. https://www.esccap.fr/ par-fiches/gliricola-porcelli.html

Hawkins, M.G., Bishop, C.R. (2012). Disease problems of Guinea Pigs in Quesenberry \& Carpenter. Ferrets, Rabbits and Rodents. Clinical Medicine and Surgery, Elsevier Saunders, 304.

Hillyard, P.D. (1996). Ticks of North-West Europe. The Linnean Society of London and The Estuarine and Coastal Sciences Assocation by Field Studies Council. London: The Natural History Museum.

Izdebska, J.N., Rolbiecki, L. (2015). New data on occurrence of Demodex flagellurus (Acari, Demodecidae) - rarely recorded parastie from the house mouse Mus musculus (Rodentia, Muridae). Annals of Parasitology, 61(1), 37-41.

Jańczak, D., Ruszczak, A., Kaszak, I., Gołąb, E., Barszcz, K. (2017). Clinical aspects of demodicosis in veterinary and human medicine. Medycyna Weterynaryjna, 73(5), 265-271.

Kadulski, S. (2007). Pasożyty zewnętrzne lisa (Vulpes vulpes L.) na Pomorzu Gdańskim. Wiadomości Parazytologiczne, 53(supl.), 144. [In Polish]

Kadulski, S., Izdebska, J.N. (2009). New data on distribution of Dermacentor reticulatus (Fabricius, 1794) (Acari: Ixodidae) in Poland. In: A. Buczek, C. Błaszak (eds.), Stawonogi. Inwazje i ich ograniczenia. Lublin: Wydawnictwo Akapit, 53-58. [In Polish]

Karaer, Z., Kurtdede, A., Ural, K., Sari, B., Cingi, C.C., Karakurum, M.C., Haydardedeoglu, A.E. (2009). Demodicosis in a Golden (Syrian) hamster (Mesocricetus auratus). Ankara Üniversitesi Veteriner Fakültesi Dergisi, 56, 227-229.

Kilar, P. (2011). Ticks attacking domestic dogs in the area of the Rymanów district, Subcarpathian province, Poland. Wiadomości Parazytologiczne, 57(3), 189-191.

Klockiewicz, M. (1992). Inwazje pasożytniczych roztoczy u kotów i psów. Magazyn Weterynaryjny, 12, 56. [In Polish]

Kocoń, A., Nowak-Chmura, M., Kłyś, M., Siuda, K. (2017). Ticks (Acari: Ixodida) attacking domestic cats (Felis catus L.) in southern Poland. In: A. Buczek, C. Błaszak (eds.), Stawonogi: w środowisku miejskim i podmiejskim. Lublin: Koliber, 51-61. [In Polish/English]

Kotomski, G. (2000). Przegląd chorób pasożytniczych kotów wywoływanych przez stawonogi. Magazyn Weterynaryjny, 15(supl. koty). [In Polish]

Krassowska, U. (2014). Zwierzęta w polskich domach. Zespół badań społecznych. TNS Październik 2017. http://www.tnsglobal.pl/archiwumraportow/files/2014/11/K.073_Zwierz\%C4\%99ta_w_ polskich_domach_O10a-14.pdf

Lasota-Moskalewska, A. (2005). Zwierzęta udomowione w dziejach ludzkości. Warszawa: Wydawnictwo UW, 211-217. [In Polish]

Lingonathus setosus. Veterian Key Fastest Veterinary Medicine Insight Engine. https://veteriankey.com/ arthropods-that-infect-and-infest-domestic-animals/

Mederle, N., Indre, D. (2009). Trixacarus caviae infestation in Guinea pigs case report. Lucrári Stiintifice Mediciná Veterinará, 42(1), 101-104.

Mihalca, A.D., Dumitrache, M.O., Magdaş, C., Gherman, C.M., Domşa, C., Mircean, V., Ghira I.V., Pocora ,V., Ionescu ,D.T., Sikó Barabási, S., Cozma, V., Sándor, A.D. (2012). Synopsis of the hard ticks 
(Acari: Ixodidae) of Romania with update on host associations and geographical distribution. Experimental and Applied Acarology, 58(2), 183-206.

Michalik, J., Sikora, B., Górecki, G., Wierzbicka, A., Wodecka, A. (2010). Fall-winter infestation of red foxes (Vulpes vulpes) with ixodid ticks in west-central Poland. In: A. Buczek, C. Błaszak (eds.), Stawonogi. Ekologiczne i patologiczne aspekty układu pasożyt-żywiciel. Lublin: Wydawnictwo Akapit, 49-55. [In Polish/English]

Notoedres cati. European Scientific Counsel Companion Animal Parasites. https://www.esccap.fr/ par-fiches/notoedres-sp.html

Nowak, M. (2010). The international trade in reptiles (Reptilia). The cause of the transfer of exotic ticks (Acari: Ixodida) to Poland. Veterinary Parasitology, 169, 373-381. DOI: 10.1016/j.vetpar.2010.01.006.

Nowak, M. (2011). Discovery of Dermacentor reticulatus (Fabricius, 1794) (Acari: Amblyommidae) standings in the Lubuskie Province (Western Poland). Experimental and Applied Acarology, 54, 191197. DOI $10.1007 / \mathrm{s} 10493-010-9422-4$

Nowak-Chmura, M., Siuda, K. (2012). Ticks of Poland. Review of contemporary issues and latest research. Annals of Parasitology, 58(3), 125-155.

Nowak-Chmura, M. (2013). Fauna kleszczy (Ixodida) Europy Środkowej. Kraków: Wydawnictwo Naukowe Uniwersytetu Pedagogicznego. [In Polish]

Otodectes cynotis. Świat czarnego teriera. http://www.swiatczarnegoteriera.republika.pl/a-zdrowie_ choroby_swierzb.html

Patyk, S. (1978). Choroby inwazyjne zwierząt domowych. Warszawa: Państwowe Wydawnictwo Rolnicze i Leśne. [In Polish]

Pawełczyk, O., Pająk, C., Solarz, K. (2016). The risk of exposure to parasitic mites and insects occurring on pets in Southern Poland. Annals of Parasitology, 62(4), 337-344. DOI: 10.17420/ap6204.70.

Petney, T.N., Pfäffle, M.P., Skuballa, J.D. (2012). An annotated checklist of the ticks (Acari: Ixodida) of Germany. Systematic and Applied Acarology, 17(2), 115-170. DOI: 10.11158/saa.17.2.2

Przyjałkowski, Z. (1977). Najważniejsze wewnętrzne i zewnętrzne pasożyty zwierząt laboratoryjnych i ich znaczenie. Zwierzęta Laboratoryjne, 14, 33. [In Polish]

Sadzikowski, A.B., Gundłach, J.L. (2004). Parazytologia i parazytozy zwierząt. Warszawa: Państwowe Wydawnictwo Rolnicze i Leśne. [In Polish]

Saevik, B.K., Bredal, W., Ulstein, T.L. (2004). Cheyletiella infestation in the dog: observations on diagnostic methods and clinical signs. Journal of Small Animal Practice, 45(10), 495-500. DOI: 10.1111/ j.1748-5827.2004.tb00194.x

Sandner, H. (1976). Owady. Warszawa: Państwowe Wydawnictwo Naukowe. [In Polish]

Sarcoptes scabiei var. canis. VectorBase Bioinformatics Resource for Invertebrate Vectors of Human Pathogens. https://www.vectorbase.org/taxonomy/arachnida

Sideroferus lunula. Federmilben. http://www.federmilben.de/34.htm

Siuda, K. (1993). Kleszcze Polski (Acari: Ixodida). Część II. Systematyka i rozmieszczenie. Warszawa: Polskie Towarzystwo Parazytologiczne. [In Polish]

Siuda, K., Pet'ko, B., Stanko, M., Karbowiak, G. (2002). The distribution of the tick Ixodes ricinus (Linnaeus, 1758) (Acari: Ixodida: Ixodidae) on the area of Kraków. In: S. Ignatowicz (ed.), Postępy polskiej akarologii. Warszawa: Wydawnictwo Szkoły Głównej Gospodarstwa Wiejskiego, 119-130. [In Polish]

Siuda, K., Nowak, M., Grycz, K., Solarz, K. (2004). Stan wiadomości nad rozprzestrzenieniem Ixodes ricinus (Linnaeus, 1758) (Acari: Ixodida: Ixodidae) na terenie województwa małopolskiego. In: J. Partyka (ed.), Zróżnicowanie i przemiany środowiska przyrodniczo-kulturowego Wyżyny Krakowsko-Częstochowskiej 1: Ojców: Ojcowski Park Narodowy, 295-301. [In Polish] 
Siuda, K., Nowak, M., Gierczak, M., Wierzbowska, I., Faber, M. (2007). Kleszcze (Acari: Ixodida) pasożytujące na psach i kotach domowych w Polsce. Wiadomości Parazytologiczne, 53(supl.), 155. [In Polish]

Siuda, K., Nowak, M., Gierczak, M. (2010). Confirmation of occurence of Ixodes (Pholeoixodes) rugicollis Schulze et Schlotke, 1929 (Acari: Ixodidae) in Poland, including the morphological description and diagnostics features of this species. Wiadomości Parazytologiczne, 56, 39-45.

Siuda, K., Nowak-Chmura, M. (2011). Fauna of ticks (Ixodida) in the Beskid Wyspowy. In: A. Buczek., C. Błaszak (eds.), Stawonogi. Pasożyty człowieka i zwierząt. Lublin: Wydawnictwo Akapit, 13-24. [In Polish]

Stefański, W. (1968). Parazytologia weterynaryjna II. Warszawa: Państwowe Wydawnictwo Rolnicze i Leśne. [In Polish]

Stromenger, Z. (1995). Chomiki syryjskie. Państwowe Warszawa: Wydawnictwo Rolnicze i Leśne. [In Polish]

Szymański, S. (1986). Distribution of the tick Dermacentor reticulatus (Fabricius, 1794) (Ixodidae) in Poland. Acta Parasitologica Polonica, 31, 143-154.

Sychra, O. (2005). Morfological variation of Neopsittaconirmuis gracialis (Phthiraptera, Ischnocera) from budgerigar, Melopsittacus undulatus. Biologia Bratislava, 60, 2.

The results of the occurence of Trixacarus caviae. Guinea Lynx. A medical and care guide for guinea pigs. http://www.guinealynx.info/mites.htm

Trichodectes canis. Online Photo Atlas in Veterinary Disease Biology. http://atlas.sund.ku.dk/parasiteatlas/ectoparasitic_arthropod/Trichodectes_canis/

Welc-Falęciak, R., Rodo A., Siński, E., Bajer, A. (2009). Babesia canis and other tickborne infections in dogs in Central Poland. Veterinary Parasitology, 166, 191-198. DOI: 10.1016/j.vetpar.2009.09.038

Zientek, H. (2015). Encyklopedia. Małe ssaki domowe. Bielsko-Biała: Wydawnictwo Dragon, 117. [In Polish]

Zygner, W., Gójska, O., Rapacka, G., Jaros, D., Wędrychowicz, H. (2007). Hematological changes during the course of canine babesiosis caused by large Babesia in domestic dogs in Warsaw (Poland). Veterinary Parasitology, 145, 146-151. DOI: 10.1016/j.vetpar.2006.11.008

Zygner, W., Jaros, S., Wędrychowicz, H. (2008). Prevalence of Babesia canis, Borrelia afzelli and Anaplasma phagocytophilum infection in hard ticks removed from dogs in Warsaw (central Poland). Veterinary Parasitology, 153, 139-142. DOI: 10.1016 / j.vetpar.2008.01.036 

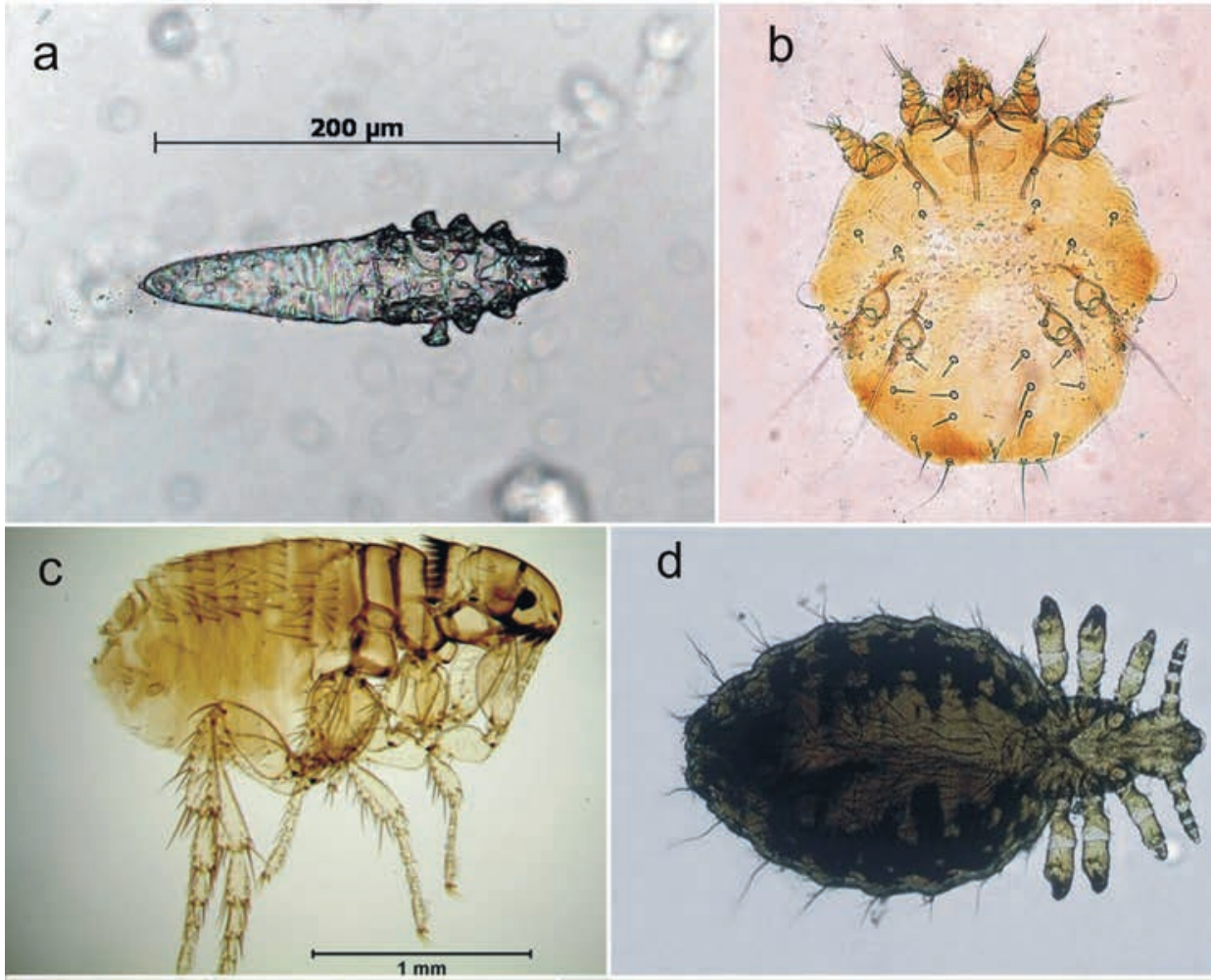

\section{d}

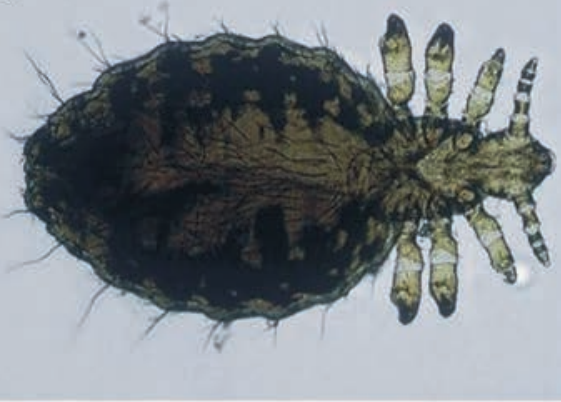

\section{e}
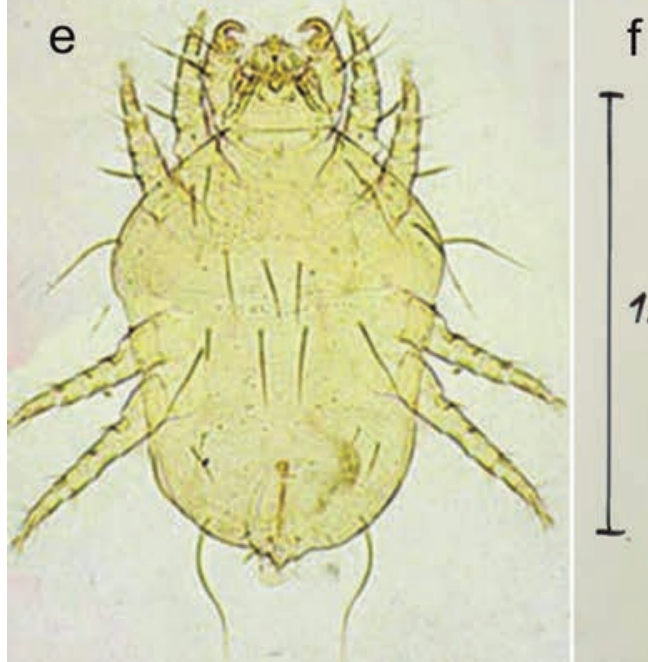

f

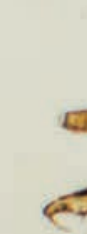

$1 \mathrm{~mm}$

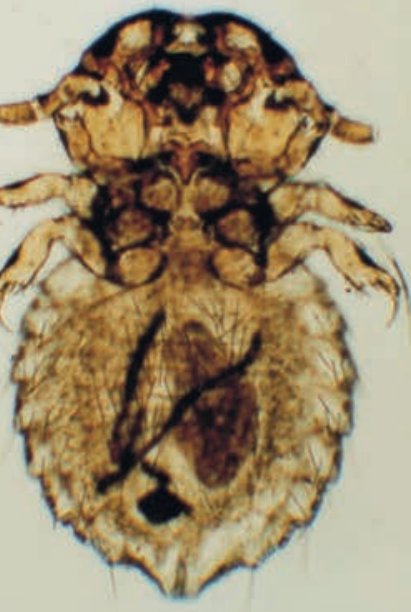

Fig. 1. Demodex canis - a (Source: http://people.upei.ca/), Sarcoptes scabiei var. canis - b (Source: https:// www.vectorbase.org), Ctenocephalides canis - c (Source: http://entnemdept.ufl.edu), Lingonathus setosus - d (Source: https://veteriankey.com), Cheyletiella yasguri - e (Source: http://www.swiatczarnegoteriera. republika.pl), Trichodectes canis - $\mathrm{f}$ (Source: http://atlas.sund.ku.dk) 


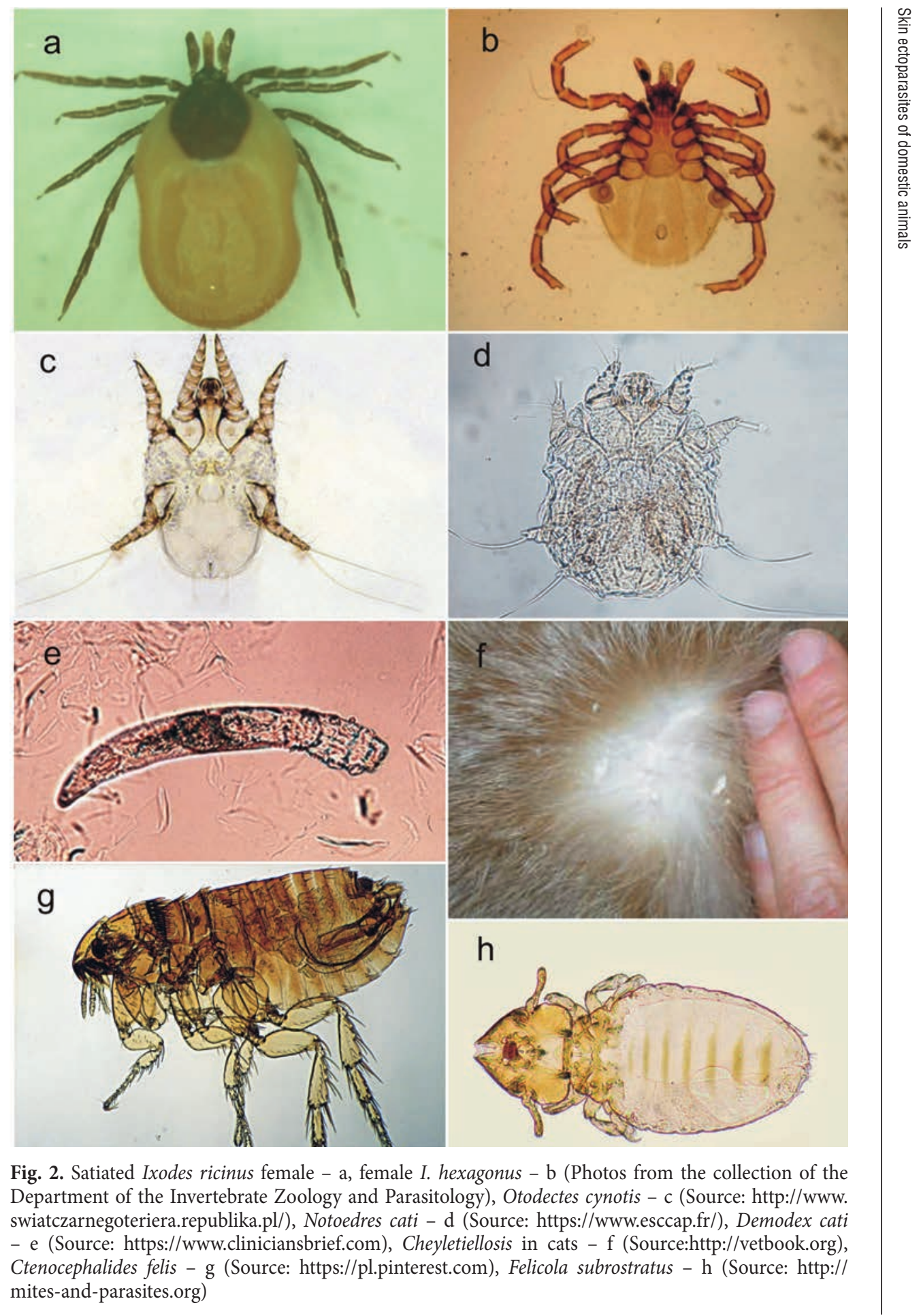




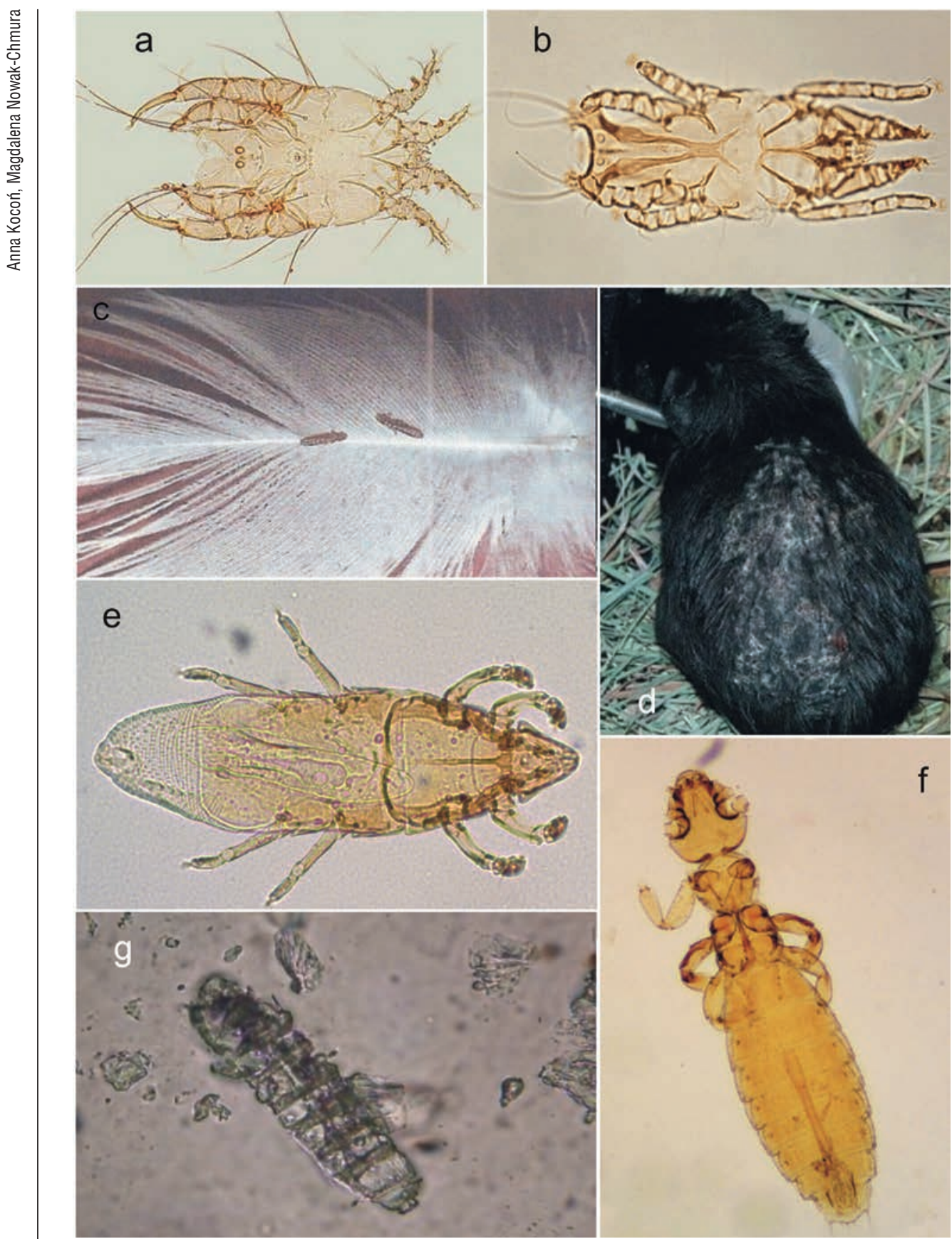

Fig. 3. Dubininia melopsittaci - a (Source: http://www.federmilben.de), Sideroferus lunula b (Source: http://www.federmilben.de), Feather-easting on feather flags - c (Source: http://www.golebiepocztowe.eu), The results of the occurence of Trixacarus caviae - d (Source: http://www.guinealynx. info), Chirodiscoides caviae - e (Source: https://www.esccap.fr), Gliricola porcelli - $\mathrm{f}$ (Source: https://www. esccap.fr), Demodex cavinae - g (Source: http://www.happy-knuffels.de) 

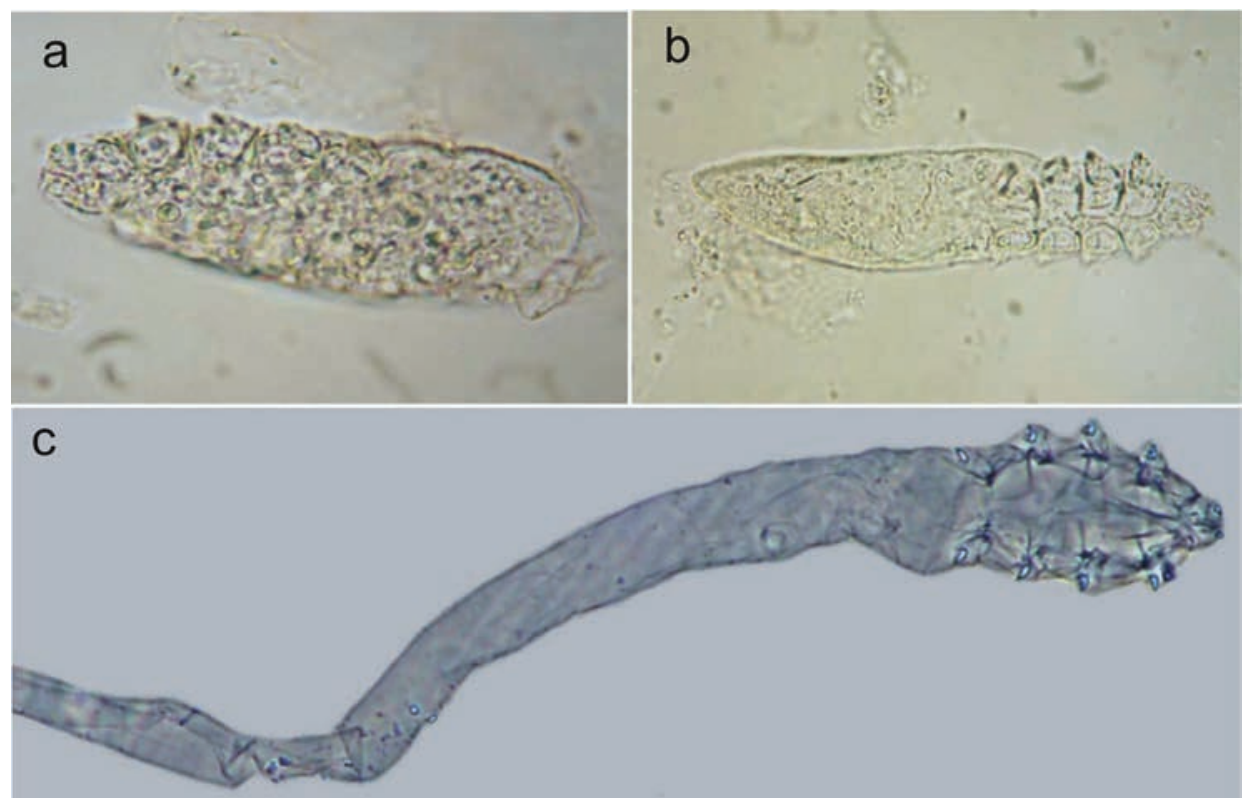

Fig. 4. Demodex criceti - a, D. aurati - b, D. flagellurus - c (Source: https://www.researchgate.net) 
Zwierzęta towarzyszące ludziom, w tym zwierzęta domowe odgrywają ważną rolę w otaczającym nas środowisku. Jednak większość z nich może być narażona na kontakt z gatunkami pasożytniczych roztoczy i owadów, o dużym znaczeniu medycznym i weterynaryjnym, stanowiących zagrożenie dla zdrowia zarówno zwierząt, jak i ludzi. Do najbardziej rozpowszechnionych ektopasożytów skórnych zwierząt należą: Demodex canis, D. cati, D. criceti, D. aurati, D. caviae, Otodectes cynotis, Sarcoptes scabiei, Cheyletiella yasguri, C. blakei, Chirodiscoides caviae, Ctenocephalides canis, C. felis, Trichodectes canis, Linognathus setosus, Felicola subrostratus, Notoedres cati, Dubininia melopsittaci, Sideroferus lunula, Neopsittaconirmus gracilis, Gliricola porcelli, Trixacarus caviae, Ixodes ricinus, I. hexagonus, I. crenulatus, I. rugicollis i Dermacentor reticulatus. Różne gatunki pasożytów zewnętrznych, które mogą być również przenoszone na ludzi są odpowiedzialne za najczęstsze choroby pasożytnicze skóry zwierząt: sarkoptozę, otodektozę, ktenocefalidozę, wszawicę, wszołowicę, demodekozę i chejletielozę. Ponadto kleszcze z rodziny Ixodidae odgrywają znaczącą rolę w przenoszeniu chorób, do najważniejszych z nich należą: borelioza z Lyme, babeszjoza, riketsjoza, erlichioza, tularemia. W niniejszej pracy przedstawiono najczęściej występujące ektopasożyty skórne u zwierząt domowych takich jak: pies domowy (Canis familiaris), kot domowy (Felis catus), papużka falista (Melopsittacus undulatus), kawia domowa (Cavia porcellus ), chomik syryjski (Mesocricetus auratus), mysz domowa (Mus musculus).

Key words: demodex, ectoparasites, fleas, lice, mites, pets, ticks

Received on: [2017.09.17]

Accepted on: [2017.11.12] 